Scots pine litter decomposition along drainage succession and soil nutrient gradients in peatland forests, and the effects of inter-annual weather variation

\title{
Laiho, $\mathrm{R}$
}

PERGAMON

2004

Laiho , R , Laine , J , Trettin , C C \& Finer , L 2004 , ' Scots pine litter decomposition along drainage succession and soil nutrient gradients in peatland forests, and the effects of inter-annual weather variation ' , Soil Biology \& Biochemistry , vol 36 , no. 7 , pp. 1095-1109 .

http://hdl.handle.net/10138/18475

http://dx.doi.org/10.1016/j.soilbio.2004.02.020

Downloaded from Helda, University of Helsinki institutional repository.

This is an electronic reprint of the original article.

This reprint may differ from the original in pagination and typographic detail.

Please cite the original version. 
Published in Soil Biology \& Biochemistry, vol. 36, pages 1095-1109, 2004.

doi: 10.1016/j.soilbio.2004.02.020

Scots pine litter decomposition along drainage succession and soil nutrient gradients in peatland forests, and the effects of inter-annual weather variation

\author{
Raija Laiho ${ }^{1,2}$, Jukka Laine ${ }^{1}$, Carl C. Trettin ${ }^{3}$ and Leena Finér ${ }^{2,4}$ \\ ${ }^{1}$ Peatland Ecology Group, Department of Forest Ecology, University of Helsinki, Helsinki, \\ Finland \\ ${ }^{2}$ Finnish Forest Research Institute, Joensuu Research Centre, Joensuu, Finland \\ ${ }^{3}$ USDA Forest Service, Southern Research Station, Center for Forested Wetlands \\ Research, Charleston, SC, USA \\ ${ }^{4}$ Faculty of Forestry, University of Joensuu, Joensuu, Finland
}

\begin{abstract}
Peatlands form a large carbon (C) pool but their $\mathrm{C}$ sink is labile and susceptible to changes in climate and land-use. Some pristine peatlands are forested, and others have the potential: the amount of arboreal vegetation is likely to increase if soil water levels are lowered as a consequence of climate change. On those sites tree litter dynamics may be crucial for the $\mathrm{C}$ balance. We studied the decomposition of Scots pine (Pinus sylvestris L.) needle and root litter in boreal peatland sites representing gradients in drainage succession (succession following water level drawdown caused by forest drainage) and soil nutrient level during several years of varying weather conditions. Neither gradient had an unambiguous effect on litter mass loss. Mass loss over 2 years was faster in undrained versus drained sites for both needle litter, incubated in the moss layer, and fine root litter, incubated in $0-10 \mathrm{~cm}$ peat layer, suggesting moisture stress in the surface layers of the drained sites limited decomposition. Differences among the drained sites were not consistent. Among years, mass loss correlated positively with precipitation variables, and mostly negatively or not at all with temperature sum. We concluded that a long-term water-level drawdown in peatlands does not necessarily enhance decay of fresh organic matter. Instead, the drained site may turn into a 'large hummock-system' where several factors, including litter quality, relative moisture deficiency, higher acidity, lower substrate temperature, and in deeper layers also oxygen deficiency, may interact to constrain organic matter decomposition. Further, the decomposition rates may not vary systematically among sites of different soil nutrient levels following water-level drawdown. Our results emphasize the importance of annual weather variations on decomposition rates, and demonstrate that single-period incubation studies incorporate an indeterminable amount of temporal variation.
\end{abstract}

Keywords: Climate change, needle litter, organic matter decomposition, peatlands, Pinus sylvestris, root litter, weather variations 


\section{Introduction}

Peatlands contain $355-45010^{15} \mathrm{~g}$ carbon (C) in the boreal and subarctic zones (Sjörs, 1981; Gorham, 1991), approximately $20-30 \%$ of the terrestrial reserve. The soil C sink of a peatland (mire) is labile, and its persistence is sensitive to weather variations, especially moisture conditions. Large soil $\mathrm{C}$ losses from pristine mires have resulted following extended summer droughts (Alm et al., 1997, 1999; Moore et al., 2002). These results have raised a postulate that long-term water-level drawdown will diminish or end the $\mathrm{C}$ sink function of a peatland. Climate change scenarios predict warmer temperatures and reduced growing season precipitation in the boreal zone, which will result in a natural drawdown of the water table in peatlands (Gorham, 1991; Gitay et al., 2001). This indirect effect of climate change could be more important than temperature in controlling the $\mathrm{C}$ balance in peatlands (Gorham, 1991; Hogg et al., 1992).

Peatlands that have been artificially drained to improve forest growth provide a basis for considering the long-term effects of changing climate conditions on this important terrestrial C reservoir. Long-term water level drawdown initiates or enhances a 'forest succession' in peatland sites (Laine et al., 1995a; Minkkinen et al., 1999; Laiho et al., 2003), unless the site is too poor in nutrients to sustain forest growth (Vasander, 1982; Minkkinen et al., 1999). In the aggrading forest, the biomass and nutrient cycles gradually shift from ground vegetation dominance to tree dominance (Laiho et al., 2003). Simultaneously, the quantity and quality of annual litterfall change. Sphagnum mosses, sedges and shrubs are the major litter sources in pristine peatlands. After drainage, the tree stand, especially its foliage and fine roots, becomes the major litter source (Laiho et al., 2003).

Change in the rates of fresh litter input and decomposition has a significant role in determining the $\mathrm{C}$ balance of peatland sites after water level drawdown, in addition to the changes taking place in the 'old' peat soil (Vompersky et al., 1992; Domisch et al., 1998; Minkkinen and Laine, 1998). Litter decomposition has been widely studied in mineral soil sites and under controlled laboratory conditions. Most of the variation in decomposition rates can be explained by litter quality, temperature and soil moisture (Berg et al., 1993; Walse et al., 1998). In pristine (undrained) peatlands, decomposition of similar litter materials is related not only to water level (e.g., Santelmann, 1992) but also to soil and/or soil water $\mathrm{pH}$ and base cation content (Verhoeven and Toth, 1995; Verhoeven et al., 1996; Szumigalski and Bayley, 1996) being generally faster in fens than bogs (Farrish and Grigal, 1988; Verhoeven et al., 1990). After permanent water level drawdown, these characteristics gradually change (Laine et al., 1995ab; Laiho et al., 1999).

Both temperature and moisture regimes in peat soils differ considerably from those of mineral soils. Further, they change gradually in the forest succession following water level drawdown (e.g., Minkkinen et al., 1999). Studies on the direct effects of water-level drawdown on in situ organic matter decomposition in peatlands are few and have produced some contradictory results (Lieffers, 1988; Bridgham et al., 1991; Minkkinen et al., 1999; Domisch et al., 2000). These studies have included only little local, between-year variation in weather conditions.

Our objective was to examine the decomposition rates of Scots pine (Pinus sylvestris L.) needle and root litter in i) a drainage succession gradient and ii) a soil nutrient gradient of peatlands during several years of varying weather conditions. The drainage succession gradient consists of peatland sites representing a single site type that were drained for forestry at different times. The soil nutrient gradient consists of peatland sites representing 
different site types that were drained at the same time. Based on earlier research on $\mathrm{CO}_{2}$ fluxes from peatland sites with varying drainage status and nutrient levels, we hypothesized that i) mass loss rates of pine litter would progressively increase following drainage as the depth to water table increases (e.g., Silvola et al., 1996), and ii) mass loss rates of pine litter would follow the original (pre-drainage) soil nutrient gradient being greatest in the most nutrient-rich site (e.g., Martikainen et al., 1995).

\section{Material and methods}

\subsection{Study sites}

Drainage succession gradient

Four tall sedge pine fen (VSR in the Finnish classification, Laine and Vasander, 1996) sites were selected from an extensive database, based on studies dealing with the effects of drainage on peat properties and vegetation (Laiho and Laine, 1994, 1995; Laine et al., 1995a; Weiss et al., 1998; Laiho et al., 1999), to form a best-possible post-drainage succession chronosequence. One of the sites was pristine while the others had been drained at different times to improve forest growth (Table 1). Thus the drained sites have been exposed to a lowered water level, and consequent changes in the ecosystem processes, for different lengths of time, varying from 23 to 57 years. All sites were located near Orivesi in southern Finland $\left(61^{\circ} 35^{\prime}-61^{\circ} 52^{\prime} \mathrm{N}, 24^{\circ} 05^{\prime}-24^{\circ} 25^{\prime} \mathrm{E}, 139-150 \mathrm{~m}\right.$ a.s.l.). Ditch spacing in the drained sites was about $40 \mathrm{~m}$. The drained sites were not further managed after ditching. However, the site drained in 1937 was disturbed by logging operations 1.5 years after the start of this experiment; as a result the site was subsequently abandoned.

A mosaic-like pattern of low treed hummocks and treeless lawns (intermediate level between dry hummock and wet hollow level) is typical of this site type in its natural (undrained) state. The tree stand is sparse and dominated by Scots pine, usually with some white birch (Betula pubescens Ehrh.). Mire dwarf shrubs (Betula nana L., Ledum palustre L., Vaccinium uliginosum L.) occur on hummocks. Minerotrophic tall sedge species (Carex lasiocarpa Ehrh., Carex rostrata Stokes) dominate the field layer of lawns. In the moss layer, oligo-ombrotrophic Sphagna (Sphagnum fallax (Klinggr.) Klinggr., Sphagnum angustifolium (Russ.) C. Jens.) are predominant. The peat is Carex-dominated. After drainage, sedges disappear within a few years. Mire dwarf shrubs usually increase at first, and then gradually decrease as tree canopy cover increases, giving way to forest species like Vaccinium vitis-idaea L. Sphagnum mosses are gradually replaced by such forest species as Pleurozium schreberi (Brid.) Mitt., even though S. russowii Warnst. and other Sphagnum species may still be abundant on old drained sites. Plant species composition in these sites has been described in more detail by Laiho (1996).

Soil nutrient gradient

Three drained sites of different soil nutrient levels were chosen for this part of the study (Table 1). They represent more than $40 \%$ (ca. 2.3 mill. ha) of the peatland area drained for forestry in Finland (Keltikangas et al., 1986). A meso-oligotrophic tall sedge fen (VSN sensu Laine and Vasander, 1996) and an oligotrophic tall sedge pine fen (VSR) were located in Orivesi $\left(61^{\circ} 48^{\prime} \mathrm{N}, 24^{\circ} 19^{\prime} \mathrm{E}, 150 \mathrm{~m}\right.$ a.s.l.) and an ombrotrophic dwarf-shrub pine 
bog (IR) in Rääkkylä (62 $14^{\prime} \mathrm{N}, 2^{\circ} 50^{\prime} \mathrm{E}, 81 \mathrm{~m}$ a.s.l.). The soil nutrient gradient refers to the pre-drainage situation (that is well known for our sites), and has been recognized on the basis of plant species composition. Thus it describes in principle rather the availability than the total concentrations of nutrients (e.g. Bragazza and Gerdol 2002). The sites in Orivesi were drained in 1961 with a 40 m ditch spacing and the site in Rääkkylä in 1967 with a 50 $\mathrm{m}$ ditch spacing. The originally nearly treeless VSN site was NPK-fertilized and planted with Scots pine after ditching. The originally wooded VSR and IR sites were not further managed after ditching. The VSR site is the same as the 30-year-old drained site in the drainage succession gradient data.

The field layer vegetation on the VSN site was rather sparse and characterized by Cyperaceous species (Carex echinata Murray, Carex chordorrhiza L. fil., Eriophorum vaginatum L.), grasses (Agrostis canina L.) and herbaceous species (Dryopteris carthusiana (Vill.) H.P. Fuchs, Epilobium angustifolium (L.) Scop., Trientalis europea L., Melampyrum pratense L.). Dwarf-shrubs (e.g., Vaccinium vitis-idaea, Betula nana) and taller shrubs (e.g., Salix phylicifolia L.) were found only sporadically. The vegetation on the VSR site was fairly similar, but Eriophorum vaginatum had a larger cover and taller shrubs were not observed. The field layer of the IR site (described by Finér and Brække, 1991) was dominated by the mire dwarf shrubs Betula nana, Ledum palustre, Calluna vulgaris L. Hull, Chamaedaphne calyculata L. Moench and Vaccinium uliginosum, and the forest dwarf shrubs Vaccinium myrtillus L. and Vaccinium vitis-idaea. Eriophorum vaginatum and Carex globularis L. were the only Cyperaceous species and Rubus chamaemorus L. the only herb in the field layer and they all occurred only sporadically. Moss layer was dominated by Pleurozium schreberi (coverage 60\%) and Sphagna (altogether 30\%).

\subsection{Decomposition measurements}

Dry mass loss of Scots pine needle, small root (diameter 2-5 $\mathrm{mm}$ ) and fine root (diameter $<2 \mathrm{~mm}$ ) litter (Table 2) was monitored over 4, 12 and 24 month periods. The needle litter was collected from our ombrotrophic study site with litter traps (Finér 1996). The root litter was obtained from nursery-grown Scots pine seedlings.

Several litterbag sequences (referred to in the following as incubation series) were installed in years 1992-1996 (Table 3). Twenty 10 x $10 \mathrm{~cm}$ nylon mesh bags with each litter type were prepared for each site, incubation depth and incubation period. Mesh size was $1 \mathrm{x} 2$ $\mathrm{mm}$ for needles and small roots, and smaller, $1 \times 1 \mathrm{~mm}$ for fine roots to prevent physical losses of the fine material. The litter materials were dried at $60^{\circ} \mathrm{C}$ before determining the initial mass. Sample size was approximately $1 \mathrm{~g}$ for needles and small roots, and $0.7 \mathrm{~g}$ for fine roots.

The bags were placed systematically across $600-1500 \mathrm{~m}^{2}$ plots established on each site. On drained sites the plots extended from ditch to ditch. The needle litterbags were placed horizontally below the living (green) moss layer. Twenty root litterbags of each type per site were placed vertically in the $0-10 \mathrm{~cm}$ peat layer (zero-level below the living moss layer) and another twenty in the 10-20 cm layer. Installation took place in the end of May and recovery in the end of either September or May. 


\subsection{Environmental variables}

Weather data (monthly mean air temperatures and precipitation sums, effective air temperature sums with $5^{\circ} \mathrm{C}$ threshold value, Table 4) were estimated for each site from the measurement data of the Finnish Meteorological Institute, using models developed by Ojansuu and Henttonen (1983). These models apply longitude, latitude, height above sea level, sea index and lake index as independent variables. Distance from the sites to the closest weather stations varied from 6 to $25 \mathrm{~km}$.

Water table depth was monitored on the sites during the growing seasons. For some sites, however, the data were defective, and site-wise between-year variation could not be used in the models (see below). Consequently, between-site variation in soil moisture was described using the average growing-season water level for each site (Table 1), while between-year variation was covered by the weather variables (see Lähde, 1969).

\subsection{Statistical analyses}

An angular transformation $\left(\mathrm{x}^{\prime}=\operatorname{arcsine} \sqrt{ } \mathrm{x}\right)$ was done for the mass loss (fraction) values (range 0-1) before statistical testing to remedy the slight non-normality associated with the percentage values.

We analyzed whether there was significant variation in mass loss among sites, years, incubation periods and litter types using repeated-measures analysis of variance. Site, starting year of an incubation series, and litter type were used as grouping factors. For root litters, there were two within-factors: time (within an incubation series) and incubation depth. For needle litter, there was only one within-factor: time. For the temporally nonuniform drainage succession gradient data, the analysis was applied separately to those subsets that had similar incubation periods (Table 3). These analyses revealed several highly significant interactions between litter type and other variables ( $p$-values $<0.001$ for littertype*site, litter-type*starting-year, incubation-time* ${ }^{*}$ site*litter-type, and depth*litter-type). Consequently, the final analyses were performed for each litter type separately. Sidak adjustment was used for pairwise multiple comparisons of means. In cases where the transformation could not remedy the heteroscedasticity in the data, Dunnett's T3 test, which does not assume equal variances, was used for multiple comparisons. The ANOVAs were done using SPSS for Windows 9.0.1.

Models were constructed to identify ecological factors controlling the variation in the mass loss of the different litter types. Because of the hierarchical data structure, a mixed (multilevel) model approach was used (e.g., Goldstein, 1995). Thus, we were able to include all data in the model analysis without a pseudoreplication problem. We identified three hierarchical levels, or potential sources of variation, in the data: i) between sites, ii) within sites between incubation series (with different starting years), and iii) within sites between incubation locations.

The mixed models had the following form:

$y_{\mathrm{ijk}}=\alpha_{\mathrm{ijk}}+\beta_{1} x_{1 \mathrm{ijk}}+\beta_{2} x_{2 \mathrm{ijk}}+\ldots+\beta_{\mathrm{n}} x_{\mathrm{nijk}}+v_{\mathrm{k}}+u_{\mathrm{jk}}+\varepsilon_{\mathrm{ijk}}$

where $y_{i j k}$ is the cumulative mass loss for the incubation location $\mathrm{i}$ within incubation series $\mathrm{j}$ in site $\mathrm{k}$. The fixed part consists of intercept $\alpha$, and site and weather characteristics $\mathrm{x}_{1 \mathrm{ijk}}{ }^{-}$ $\mathrm{x}_{\mathrm{nijk}}$ with parameters $\beta_{1^{-}} \beta_{\mathrm{n}}$. In the random part, $\mathrm{v}_{\mathrm{k}}$ represents the variance derived from 
sites $\mathrm{k}, \mathrm{u}_{\mathrm{jk}}$ is the variance derived from incubation series (starting-years) $\mathrm{j}$ in site $\mathrm{k}$, and $\varepsilon_{\mathrm{ijk}}$ accounts for the within-site variation between incubation locations. We assumed that with inclusion of proper site and weather variables in the fixed part, $\mathrm{v}_{\mathrm{k}}$ and $\mathrm{u}_{\mathrm{jk}}$ would become insignificant, whereas $\varepsilon_{\mathrm{ijk}}$ would remain significant because of the inherent spatial heterogeneity of the incubation matrix (microtopography, patchy vegetation, soil heterogeneity; e.g., Belyea, 1996).

The estimation was done by using MLwiN software (Rasbash et al., 2000), which estimates the fixed and random parameters simultaneously. We applied the restricted iterative generalised least square (RIGLS) method. The significance of the variables was evaluated based on their parameter standard error (parameter value should be at least twice its s.e.). The value of $-2 * \log$-likelihood was used to compare models of increasing complexity. Additionally, systematic bias and standard errors of the estimates produced by the fixed part were evaluated. The models were fitted to all data combined, because the separate data sets were too small for efficient modeling with this method.

\section{Results}

\subsection{Variation in mass loss}

Effect of water level drawdown

Mass loss during 12 and 24-month periods was compared among undrained and drained sites using the drainage succession gradient data set (Table 3). The effects of site, starting year, incubation time and depth, plus several interactions, were significant for all litter types (App. 1). The cumulative mass loss over 24 months from both needles and fine roots (diameter $<2 \mathrm{~mm}$ ) was significantly higher in the undrained site (Fig. 1, Table 5; App. 1).

When subsets of the incubation periods were analyzed, the differences among the drained sites were not consistent (App. 1). Small root (diameter 2-5 mm) mass loss over 24 months was most rapid in the site drained in 1970, otherwise there were no consistent differences among sites. Overall mass loss from fine roots was slowest in the site drained in 1961. This was due to the slow progress of mass loss in the deeper layer $(10-20 \mathrm{~cm})$. Otherwise the drained sites did not differ from each other.

\section{Effect of soil nutrient level}

Before drainage, two of the soil nutrient gradient sites were minerotrophic, the third being ombrotrophic, and there was an interaction between the nutrient and moisture regimes of these sites. The meso-oligotrophic (minerotrophic) site was the wettest and the ombrotrophic site the driest. At the time of our study following drainage, the sites formed a clear gradient in the concentrations of mineral nutrients, except for K (Table 1).

Across the soil nutrient gradient, the main effects of site and starting year, plus their interaction, were highly significant for all litter types (App. 2). The effects of incubation time and depth were highly significant as well, as were many of their interaction terms. The patterns of mass loss differed somewhat between litter types, however (Fig. 2, Table 6). Mass loss from needle litter followed the soil nutrient gradient, being most rapid in the meso-oligotrophic site and slowest in the ombrotrophic site (Fig. $2 ; \mathrm{p}<0.015$ for all pairs). Small root mass losses followed the same pattern but not as clearly, only the mass loss 
values of the meso-oligotrophic site differed significantly or almost significantly from the others ( $\mathrm{p}<0.001$ for meso-oligotr. vs. ombrotr., $\mathrm{p}=0.064$ for meso-oligotr. vs. oligotr., $\mathrm{p}=0.256$ for oligotr. vs. ombrotr.). In contrast, fine root litter mass loss was most rapid in the ombrotrophic site, whereas the other two sites did not differ from each other $(\mathrm{p}=0.006$ for meso-oligotr. vs. ombrotr., $\mathrm{p}=0.875$ for meso-oligotr. vs. oligotr., $\mathrm{p}=0.022$ for oligotr. vs. ombrotr.).

\subsection{Factors controlling the mass losses}

Needle litter

The model analysis of the combined data set revealed that needle litter mass loss correlated more with precipitation variables than the temperature sum (Table 7, Figs 3 and 4). Mass loss decreased with increasing water table depth, being fastest on the undrained site, where there was also more within-site variation than in the drained sites (data not shown), probably caused by the hummock-hollow variation. The positive effect of soil nitrogen concentration on needle mass loss was not significant but improved the fit of the model slightly. The fixed effects accounted for $99 \%$ of the variation in the mean mass loss values of needle litter at the sites, with a $4.2 \%$ s.e.e. (standard error of estimate).

Fine root litter

Mass loss from fine root (diameter $<2 \mathrm{~mm}$ ) litter was faster in the $0-10 \mathrm{~cm}$ layer than in the 10-20 cm layer (Table 7). Among years, fine root litter mass loss correlated negatively with temperature sum, and positively with most precipitation variables (Figs 3 and 4). Mass loss slowed down with increasing tree stand volume. The fixed effects accounted for $99 \%$ of the variation in the mean mass loss values of needle litter at the sites, with a $3.3 \%$ s.e.e.

Small root litter

Mass loss from small root (diameter 2-5 mm) litter also was faster in the 0-10 cm layer than in the 10-20 cm layer (Table 7). Among years, mass loss correlated positively with total amounts of winter (i.e. October-May) and summer (June-September) precipitation. Mass loss was higher where the proportion of birch in the tree stand of the site was high. The fixed effects accounted for $99 \%$ of the variation in the mean mass loss values of small root litter at the sites, with a $2.3 \%$ s.e.e.

\section{Discussion}

\subsection{Effect of water-level drawdown}

We were surprised that Scots pine litter decomposed as fast or faster in the undrained site as compared to the drained sites. This finding is contrary to the commonly accepted paradigm that water level drawdown improves the conditions for aerobic decay, thereby enhancing organic matter decomposition rates (e.g., Trettin et al., 1995). Accordingly, some factor(s) that regulate decomposition may either remain unfavorable, or become unfavorable following water-level drawdown. This effect persists across drainage age, since there were no consistent differences in decomposition rates among our drained sites, contrary to our hypothesis. Consideration of the experimental approach and abiotic factors affecting decay provides insight into this paradox. 
Since needle litter falls onto the mire surface, we incubated our needle samples within the living moss layer (see Morrison, 2003). Even in the hollows of the undrained site, these samples would have been in oxic conditions most of the unfrozen time. Thus, anoxia would not limit decomposition of needle litter in any of the sites.

Peat soils generally have a capillary fringe that reaches the surface when the water table is within 30 to $40 \mathrm{~cm}$, only in highly decomposed soils may it reach the surface when the water table is within $60 \mathrm{~cm}$ (Verry, 1997). The water table was frequently below $40 \mathrm{~cm}$ during the growing seasons in the drained sites, but seldom in our undrained site, or wet pristine peatlands in general in our climate (e.g., Lähde, 1971; Alm et al., 1999). When the water level is $40 \mathrm{~cm}$ below the surface, the top $5 \mathrm{~cm}$ of soil may experience severe drought in the drained sites (Fig. 5). Thus, we postulate that drought limited needle litter decomposition in the drained sites to such an extent that mass loss rates remained slower than in the pristine mire.

Root litter was incubated above $(0-10 \mathrm{~cm})$ or at $(10-20 \mathrm{~cm})$ the level of water table variation during the growing season at the undrained site; at the drained sites even the deeper incubation depths would be above the water level variation most of the time. As the aerobic limit is usually $5-30 \mathrm{~cm}$ nearer to the peatland surface than the water level during summer months (Lähde, 1969), anaerobic or reducing conditions may have impeded root litter decomposition even in the drained sites, especially in the deeper incubation depth.

Soil temperature and acidity may also contribute to reduced decomposition after water-level drawdown (Bergman et al., 1999). Initially, during 1-3 years following water-level drawdown, the growing-season temperatures in surface peat may increase (Lieffers, 1988). Generally, however, in drained peatlands with a tree cover, temperatures remain colder than in pristine sites (Hökkä et al., 1997; Venäläinen et al., 1999). Minkkinen et al. (1999) observed that this difference may extend at least to a depth of $50 \mathrm{~cm}$. On a sedge-peat site, the temperature sum $\left(0^{\circ} \mathrm{C}\right.$ threshold $)$ of the surface soil $(0-25 \mathrm{~cm})$ may be 400 d.d. higher in the pristine, wet conditions than after long-term water-level drawdown (Laine et al., 2002). Thus, while moisture deficiency may act to slow down decomposition in the surface layers of drained peatlands, cold temperatures may have a similar effect in deeper peat layers. Further, the acidity of surface peat increases after long-term water-level drawdown (Laine et al., 1995ab; Minkkinen et al., 1999; Table 1).

Ours is not the first study to consider the effects of drainage on organic matter decomposition; unfortunately the findings are not consistent. Lieffers (1988) compared the mass loss of Sphagnum and cellulose at $0-10$ and $30 \mathrm{~cm}$ below the surface layer in drained and undrained peatlands. Similar to our conclusion, he attributed the null difference in the surface layer to moisture stress. However, at $30 \mathrm{~cm}$ below the peat surface mass loss for both materials was more rapid in the drained site. Domisch et al. (2000) also observed that mass loss of pine needle and root litter was not clearly affected by site drainage.

\subsection{Effect of soil nutrient level in drained sites}

Generally, there were no big differences in mass loss rates among the sites of varying nutrient level. The needle litter in the soil nutrient gradient data set supported the hypothesis that decomposition rates followed the fertility gradient, being highest in the mesooligotrophic site. In contrast, mass loss of fine root litter varied in reversed order among sites, being highest in the ombrotrophic site. We suspect that the fine root litter from 
nursery-grown pine seedlings may have been a material preferred by decomposers especially in the ombrotrophic site, where inherently, litter material consists of moss, shrub and tree remains that are in general not readily decomposable (e.g., Taylor et al., 1991).

While the soil nutrient gradient data set was too small for separate modeling analyses, the combined data could not be used to analyze the effects of the soil nutrient level as such. This is because in drained sites, the nutrient concentrations of surface peat are affected by the secondary succession induced by water-level drawdown. The concentrations of base cations usually decrease and those of $\mathrm{N}$ and $\mathrm{P}$ may increase especially during the early stages of the succession (Laiho and Laine, 1994, 1995; Laiho et al., 1999). In the models for all data combined, inclusion of the peat $\mathrm{N}$ concentration stabilized the estimates of needle litter mass loss slightly; when analyzed separately this positive effect of $\mathrm{N}$ was by no means unambiguous, however. Clearly, the soil nutrient gradient does not unambiguously describe the decomposition potential of various litter materials (also, Domisch et al., 2000). More fundamentally, these results demonstrate the complexity in partitioning the effects of soil nutrients and litter quality.

\subsection{Effect of annual weather variations}

Temperature sum varied from about 1000 to $1300-1350$ d.d. among the study years (Table 4), varying less among sites than among years. The site drained in 1970 had the warmest air temperatures, and the mire area where the undrained site and the site drained in 1961 were located had the coldest, the difference being on average about 40 d.d. There was no clear correlation between temperature sum and growing season precipitation sum (summer precipitation) during the study years.

Surprisingly, the effect of temperature sum on fine root litter decomposition was negative during the 4- and 12-month incubation periods (Fig. 3, Table 7): mass losses were smaller during years of higher temperature sums. Needle litter mass loss had no obvious relationship with the cumulative temperature sum. Recent laboratory and field experiments have shown unambiguously that in favorable moisture conditions, higher temperatures result in more rapid decomposition in peat soils (Hogg et al., 1992; Domisch, 2000). The negative or lacking temperature effect combined with the largely positive effect of summer precipitation suggests that in general (and not only relative to pristine sites), not temperature but either drought or oxygen deficiency limited early decomposition in our drained study sites (the 4and 12-month incubation data sets did not involve undrained vs. drained comparisons). Drought, especially, would be enhanced in warmer summers. For needle litter, the limiting factor was most likely drought, as concluded previously. For root litter decomposition, however, oxygen deficiency may also be in effect (Lähde, 1969, 1971).

Interestingly, with advancing decomposition, the relation of mass loss to temperature sum seems to be turning positive (Fig. 3), especially in the case of the small root litter. Such an effect would indicate a shift in strength of the temperature vs. moisture response functions with the changing chemical quality of the decomposing material. A possible mechanism could also be different moisture and/or temperature optima of decomposers responsible for early and advanced decay (non-structural vs. structural C compounds): The enchytraeid Cognettia sphagnetorum Vejd., that may be crucial for the onset of decomposition in organic soils (Cole et al., 2000), thrives in relatively wet and cool conditions (Briones et al., 1997), while cellulose-decomposing bacteria and fungi favor relatively dry conditions 
(Paarlahti and Vartiovaara, 1958). We still know little of the moisture optima of peatland decomposers in relation to temperature, especially in relatively dry conditions with water levels below $40-50 \mathrm{~cm}$.

The role of winter precipitation in the models (Table 7) largely accounts for the differences between the 4- and 12-month mass losses. These differences, depicting mass loss in October-May, ranged from 5 to 12 percentage units for needle litter and from -3 to 13 for root litter. In our data, the relation of winter precipitation to mass losses was slightly nonlinear (not shown) in the manner of summer precipitation (Fig. 4).

Our models were constructed only to explore which factors correlated with mass losses, they cannot be generalized. One also has to bear in mind that they are statistical models that do not indicate causal relationships. Simple variables summarizing the weather conditions during incubation accounted for a surprisingly large amount of the year-to year variation in mass loss. There still remained significant variation between years in needle and small root mass losses, however, which presumably would have become insignificant with the inclusion of 'proper' weather variables. None of the models left any significant variation between the sites. This means that the fixed variables were able to cover the variation in mass losses between sites. The variation within sites remained significant in each model, as was expected.

\subsection{Conclusions}

Tree stand is the major litter source following water-level drawdown of wooded peatlands (Laiho et al. 2003). This study demonstrates that a long-term water-level drawdown in peatlands does not necessarily enhance decay of fresh organic matter. Instead, the drained site may turn into a 'large hummock-system' where several factors, including litter quality, relative moisture deficiency, higher acidity, lower substrate temperature, and in deeper layers also oxygen deficiency, may interact to constrain organic matter decomposition. As such, our results support the findings of Minkkinen and Laine (1998) and Minkkinen et al. (1999) that in some sites, the change in peat $\mathrm{C}$ balance may be positive even after long-term water-level drawdown, in part due to accumulation of recently-produced organic matter. Our results together with those of Domisch et al. (2000) suggest that the decomposition rates of different Scots pine litters may not vary systematically among sites of different soil nutrient levels following water-level drawdown. The mismatch of our findings with our initial hypotheses that were based on $\mathrm{CO}_{2}$ efflux results emphasizes that the effluxes, which include both microbial and root respiration, cannot be used as direct estimates of differences in decomposition rates among sites. We have also shown that consideration of annual weather variations is an important factor when comparing the decomposition responses across sites.

\section{Acknowledgments}

We thank Pekka Järviluoto, Jouni Meronen, Seija Repo and Veijo Tukiainen for their invaluable contribution in the field and laboratory work, and Juha Lappi for useful comments on multilevel models. 


\section{References}

Alm, J., Talanov, A., Saarnio, S., Silvola, J., Ikkonen, E., Aaltonen, H., Nykänen, H., Martikainen, P.J., 1997. Reconstruction of the carbon balance for microsites in a boreal oligotrophic pine fen, Finland. Oecologia 110, 423-431.

Alm, J., Schulman, L., Silvola, J., Walden, J., Nykänen, H., Martikainen, P.J., 1999. Carbon balance of a boreal bog during a year with an exceptionally dry summer. Ecology 80, 161-174.

Belyea, L.R. 1996. Separating the effects of litter quality and microenvironment on decomposition rates in a patterned peatland. Oikos 77, 529-539.

Berg, B., Berg, M.P., Bottner, P., Box, E., Breymeyer, A., Calvo de Anta, R., Couteaux, M., Escudero, A., Gallardo, A., Kratz, W., Madeira, M., Mälkönen, E., McClaugherty, C., Meentemeyer, V., Munoz, F., Piussi, P., Remacle, J., Virzo de Santo, A., 1993. Litter mass loss rates in pine forests of Europe and Eastern United States: some relationships with climate and litter quality. Biogeochemistry 20, 127-159.

Bergman, I., Lundberg, P., Nilsson, M., 1999. Microbial carbon mineralisation in an acid surface peat: effects of environmental factors in laboratory incubations. Soil Biology \& Biochemistry 31, 1867-1877.

Bragazza, L., Gerdol, R., 2002. Are nutrient availability and acidity-alkalinity gradients related in Sphagnum-dominated peatlands? Journal of Vegetation Science 13, 473-482.

Bridgham, S.D., Richardson, C.J., Maltby, E., Faulkner, S.P., 1991. Cellulose decay in natural and disturbed peatlands in North Carolina. Journal of Environmental Quality 20, 695-701.

Briones, M.J.I., Ineson, P., Piearce, T.G., 1997. Effects of climate change on soil fauna; responses of enchytraeids, Diptera larvae and tardigrades in a transplant experiment. Applied Soil Ecology 6, 117-134.

Cole, L., Bardgett, R.D., Ineson, P., 2000. Enchytraeid worms (Oligochaeta) enhance mineralization of carbon in organic upland soils. European Journal of Soil Science 51, 185 192.

Domisch, T., 2002. Effects of soil temperature on Scots pine biomass allocation and litter decomposition in peat. Finnish Forest Research Institute, Research Papers, 874, 65 p.

Domisch, T., Finér, L., Karsisto, M., Laiho, R., Laine, J., 1998. Relocation of carbon from decaying litter in drained peat soils. Soil Biology \& Biochemistry 30, 1529-1536.

Domisch, T., Finér, L., Laiho, R., Karsisto, M., Laine, J., 2000. Decomposition of Scots pine litter and the fate of released carbon in pristine and drained pine mires. Soil Biology \& Biochemistry 32, 1571-1580.

Farrish, K.W., Grigal, D.F., 1988. Decomposition in an ombrotrophic bog and a minerotrophic fen in Minnesota. Soil Science 145, 353-358.

Finér, L., 1996. Variation in the amount and quality of litterfall in a Pinus sylvestris L. stand growing on a bog. Forest Ecology and Management 80, 1-11.

Finér, L., Brække, F. H., 1991. Understorey vegetation on three ombrotrophic pine bogs and the effects of NPK and PK fertilization. Scandinavian Journal of Forest Research 6, 113-128.

Gitay, H., Brown, S., Easterling, W., Jallow, B., Antle, J., Apps, M., Beamish, R., Chapin, T., Cramer, W., Frangi, J., Laine, J., Lin Erda, Magnuson, J., Noble, I., Price, J., Prowse, T., Root, T., Schulze, E., Sirotenko, O., Sohngen, B., Soussana, J., Buggman, H., Egorov, C., Finlayson, M., Fleming, R., Fraser, W., Hahn, L., Hall, K., Howden, M., Hutchins, M., Ingram, J., Ju Hui, Masters, G., Megonigal, P., Morgan, J., Myers, N., Neilson, R., Page, S., Parmesan, C., Rieley, J., Roulet, N., Takle, G., van Minnen, J., Williams, D., Williamson, T., Wilson, K., Fischlin, A., Diaz, S., 2001. Ecosystems and their goods and services. In: McCarthy, J.J., Canziani, O.F., Leary, N.A., Dokken, D.J., White, K.S. (Eds.), Climate change 2001, impacts, adaptation, and vulnerability. Contribution of working group II to the third 
assessment report of the Intergovernmental Panel on Climate Change. Cambridge University Press, Cambridge, pp. 235-342.

Goldstein, H., 1995. Multilevel statistical models. $2^{\text {nd }}$ Ed. Kendall's Library of Statistics 3. Hodder Arnold, London.

Gorham, E., 1991. Northern peatlands: role in the carbon cycle and probable responses to climatic warming. Ecological Applications 1, 182-195.

Hogg, E.H., Lieffers, V.J., Wein, R.W., 1992. Potential carbon losses from peat profiles: effects of temperature, drought cycles, and fire. Ecological Applications 2, 298-306.

Hökkä, H., Penttilä, T., Siipola, M., 1997. Relationships between groundwater level and temperature in peat. In: Trettin, C.C., Jurgensen, M.F., Grigal, D.F., Gale, M.R., Jeglum, J.K. (Eds.), Northern Forested Wetlands: Ecology and Management. CRC Press, Lewis Publishers, Boca Raton, Fla, pp. 287-296.

Keltikangas, M. Laine, J. Puttonen, P., Seppälä, K., 1986. Peatlands drained for forestry during 1930-1978: results from field surveys of drained areas. Acta Forestalia Fennica 193, 1-94. (In Finnish with English summary).

Lähde, E., 1969. Biological activity in some natural and drained peat soils with special reference to oxidation-reduction conditions. Acta Forestalia Fennica 94, 1-69.

Lähde, E., 1971. On anaerobic conditions in various virgin peat soils and the significance of the aerobic limit as an indicator of site quality. Silva Fennica 5, 36-48. (In Finnish with English summary).

Laiho, R., 1996. Changes in understorey biomass and species composition after water-level drawdown on pine mires in southern Finland. Suo 47, 59-69.

Laiho, R., Laine, J., 1994. Nitrogen and phosphorus stores in peatlands drained for forestry in Finland. Scandinavian Journal of Forest Research 9, 251-260.

Laiho, R., Laine, J., 1995. Changes in mineral element concentrations in peat soils drained for forestry in Finland. Scandinavian Journal of Forest Research 10, 218-224.

Laiho, R., Sallantaus, T., Laine, J., 1999. The effect of forestry drainage on vertical distributions of major plant nutrients in peat soils. Plant and Soil 207, 169-181.

Laiho, R., Vasander, H., Penttilä, T., Laine, J., 2003. Dynamics of plant-mediated organic matter and nutrient cycling following water-level drawdown in boreal peatlands. Global Biogeochemical Cycles 17(2), 1053, doi:10.1029/2002GB002015.

Laine, J., Vasander, H., 1996. Ecology and vegetation gradients in peatlands. In: Vasander, H. (Ed.), Peatlands in Finland. Finnish Peatland Society, Helsinki, pp. 10-19.

Laine, J., Vasander, H., Laiho, R., 1995a. Long-term effects of water level drawdown on the vegetation of drained pine mires in southern Finland. Journal of Applied Ecology 32, 785-802.

Laine, J., Vasander, H., Sallantaus, T., 1995b. Ecological effects of peatland drainage for forestry. Environmental Reviews 3, 286-303.

Laine, J., Komulainen, V.-M., Laiho, R., Minkkinen, K., Rasinmäki, A., Sallantaus, T., Sarkkola, S., Silvan, N., Tolonen, K., Tuittila, E.-S., Vasander, H., Päivänen, J., 2002. Lakkasuo - opas suon ekosysteemiin (Abstract: Lakkasuo - guide to a mire ecosystem). University of Helsinki, Department of Forest Ecology Publications 26. 120 pp.

Lieffers, V.J., 1988. Sphagnum and cellulose decomposition in drained and natural areas of an Alberta peatland. Canadian Journal of Soil Science 68, 755-761.

Martikainen, P.J., Nykänen, H., Alm, J., Silvola, J., 1995. Change in fluxes of carbon dioxide, methane and nitrous oxide due to forest drainage of mire sites of different trophy. Plant and Soil 168-169, 571-577.

Minkkinen, K., Laine, J., 1998. Long-term effect of forest drainage on the peat carbon stores of pine mires in Finland. Canadian Journal of Forest Research 28, 1267-1275. 
Minkkinen, K., Vasander, H., Jauhiainen, S., Karsisto, M., Laine, J., 1999. Post-drainage changes in vegetation composition and carbon balance in Lakkasuo mire, Central Finland. Plant and Soil 207, 107-120.

Moore, T.R, Bubier, J.L., Frolking, S.E., Lafleur, P.M., Roulet, N.T., 2002. Plant biomass and production and $\mathrm{CO}_{2}$ exchange in an ombrotrophic bog. Journal of Ecology 90, 25-36.

Morrison, I.K., 2003. Decomposition and element release from confined jack pine needle litter on and in the feathermoss layer. Canadian Journal of Forest Research 33, 16-22.

Ojansuu, R., Henttonen, H., 1983. Estimation of local values of monthly mean temperature, effective temperature sum and precipitation sum from the measurements made by the Finnish Meteorological Office. Silva Fennica 17, 143-160. (In Finnish with English summary).

Paarlahti, K., Vartiovaara, U., 1958. Observations concerning the microbial populations in virgin and drained bogs. Communicationes Instituti Forestalis Fenniae 50(4), 1-38. (In Finnish with English summary).

Rasbash, J., Browne, W., Goldstein, H., Yang, M., Plewis, I., Healy, M., Woodhouse, G., Draper, D., Langford, I., Lewis, T., 2000. A user's guide to MlwiN. Version 2.1c. Centre for Multilevel Modelling, Institute of Education, University of London, 278 pp.

Santelmann, M.V., 1992. Cellulose mass loss in ombrotrophic bogs of northeastern North America. Canadian Journal of Botany 70, 2378-2383.

Silvola, J., Alm, J., Ahlholm, U., Nykänen, H., Martikainen, P.J., 1996. $\mathrm{CO}_{2}$ fluxes from peat in boreal mires under varying temperature and moisture conditions. Journal of Ecology 84, 219228.

Sjörs, H., 1981. The zonation of northern peatlands and their importance for the carbon balance of the atmosphere. International Journal of Ecology and Environmental Sciences 7, 11-14.

Szumigalski, A.R., Bayley, S.E., 1996. Decomposition along a bog to rich fen gradient in central Alberta, Canada. Canadian Journal of Botany 74, 573-581.

Taylor, B.R., Prescott, C.E., Parsons, W.J.F., Parkinson, D., 1991. Substrate control of litter decomposition in four Rocky Mountain coniferous forests. Canadian Journal of Botany 69, 2242-2250.

Trettin, C.C., Jurgensen, M.F., Gale, M.R., McLaughlin, J.A., 1995. Soil carbon in northern forested wetlands: Impacts of silvicultural practices. In: McFee, W.W., Kelley, J.M., (Eds.), Carbon Forms and Functions in Forest Soils. Soil Science Society of America, Madison, pp. 437-461.

Vasander, H., 1982. Plant biomass and production in virgin, drained and fertilized sites in a raised bog in southern Finland. Annales Botanici Fennici 19, 103-125.

Venäläinen, A., Rontu, L., Solantie, R., 1999. On the influence of peatland draining on local climate. Boreal Environment Research 4, 89-100

Verhoeven, J.T.A., Toth, E., 1995. Decomposition of Carex and Sphagnum litter in fens: Effect of litter quality and inhibition by living tissue homogenates. Soil Biology \& Biochemistry 27, 271-275.

Verhoeven, J.T.A., Maltby, E., Schmitz, M.B., 1990. Nitrogen and phosphorus mineralization in fens and bogs. Journal of Ecology 78, 713-726.

Verhoeven, J.T.A., Keuter, A., Van Logtestijn, R., Van Kerkhoven, M.B., Wassen, MM., 1996. Control of local nutrient dynamics in mires by regional and climatic factors: a comparison of Dutch and Polish sites. Journal of Ecology 84, 647-656.

Verry, E.S., 1997. Hydrological processes of natural, northern forested wetlands. In: Trettin, C.C., Jurgensen, M.F., Grigal, D.F., Gale, M.R., Jeglum, J.K. (Eds.), Northern Forested Wetlands: Ecology and Management. CRC Press, Lewis Publishers, Boca Raton, Fla, pp. 163188. 
Vompersky, S.E., Smagina, M.V., Ivanov, A.I., Glukhova, T.V., 1992. The effect of forest drainage on the balance of organic matter in forest mires. In: Bragg, O.M., Hulme, P.D., Ingram, H.A.P., Robertson, R.A. (Eds.), Peatland Ecosystems and Man: An Impact Assesment. British Ecological Society and International Peat Society, Dept. of Biological Sciences, University of Dundee, pp. 17-22.

Walse, C., Berg, B., Sverdrup, H., 1998. Review and synthesis of experimental data on organic matter decomposition with respect to the effect of temperature, moisture, and acidity. Environmental Reviews 6, 25-40.

Weiss, R., Alm, J., Laiho, R., Laine J., 1998. Modelling moisture retention in peat soils. Soil Science Society of America Journal 62, 305-313. 
Tables

Table 1. General features of the study sites: Average growing season water level (WT, $\mathrm{cm})$, tree stand stem volume in $1992\left(\mathrm{~V}, \mathrm{~m}^{3} \mathrm{ha}^{-1}\right)$, proportion of birch (Betula pubescent) in the Scots pine (Pinus sylvestris) dominated tree stands (Birch, \% of stem volume), acidity and total nutrient concentrations ( $\%$ of dry mass) in the 20 -cm surface peat layer.

\begin{tabular}{|c|c|c|c|c|c|c|c|c|c|c|}
\hline Site & WT & $\mathrm{V}^{\mathrm{a}}$ & Birch & $\mathrm{pH}^{\mathrm{b}}$ & $\mathrm{N}$ & $\mathrm{P}$ & $\mathrm{Ca}$ & S & $\mathrm{Fe}$ & $\mathrm{K}$ \\
\hline \multicolumn{11}{|c|}{ Drainage succession gradient } \\
\hline Undrained & 10 & 24 & 0 & 4.1 & 2.2 & 0.062 & 0.429 & 0.146 & 0.530 & 0.052 \\
\hline Drained 1970 & 60 & 70 & 31 & 3.1 & 2.2 & 0.065 & 0.285 & 0.185 & 0.254 & 0.028 \\
\hline Drained $1961^{\mathrm{c}}$ & 50 & 102 & 15 & 3.0 & 2.4 & 0.069 & 0.330 & 0.199 & 0.727 & 0.026 \\
\hline Drained 1937 & 70 & 150 & 9 & 3.0 & 1.9 & 0.084 & 0.138 & 0.175 & 0.300 & 0.043 \\
\hline \multicolumn{11}{|c|}{ Soil nutrient gradient } \\
\hline Meso-oligotrophic & 50 & 117 & 3 & 3.3 & 2.1 & 0.120 & 0.356 & 0.221 & 0.701 & 0.031 \\
\hline Oligotrophic $^{\mathrm{c}}$ & 50 & 144 & 10 & 3.0 & 2.3 & 0.083 & 0.277 & 0.199 & 0.355 & 0.026 \\
\hline Ombrotrophic & 50 & 134 & 0 & 3.1 & 1.1 & 0.063 & 0.232 & 0.155 & 0.127 & 0.038 \\
\hline
\end{tabular}

\footnotetext{
${ }^{a}$ Yearly values were used in the modeling

b $1: 2.5 \mathrm{v} / \mathrm{v}$ dry soil to $0.01 \mathrm{M} \mathrm{CaCl}_{2}$

${ }^{c}$ Same site, different sample plots 1995-1998
} 
Table 2. Average initial moisture content, organic matter content and element concentrations ( $\%$ of dry mass) in the litter materials used in the study. Fine roots: diameter $<2 \mathrm{~mm}$, small roots: diameter 2-5 mm.

\begin{tabular}{llllllllll}
\hline Litter type & Moisture & OM content & $\mathrm{N}$ & $\mathrm{P}$ & $\mathrm{Ca}$ & $\mathrm{Mg}$ & $\mathrm{Fe}$ & $\mathrm{K}$ \\
\hline Needles & 6.9 & 98.4 & 1.055 & 0.071 & 0.399 & 0.078 & 0.010 & 0.164 \\
Fine roots & 7.6 & 95.7 & 1.120 & 0.215 & 0.232 & 0.099 & 0.060 & 0.753 \\
Small roots & 6.7 & 98.6 & 0.609 & 0.086 & 0.092 & 0.058 & 0.004 & 0.382 \\
& & & & & & & & \\
\hline
\end{tabular}


Table 3. Incubation periods by site. Periods are from beginning of month to end of month. Periods with the same indices $(\mathrm{a}, \mathrm{b}, \mathrm{c}, \mathrm{d})$ were included in the same repeated measures ANOVAs.

Site Period Months

Drainage succession gradient

Undrained

$\begin{array}{ll}\text { June } 1995 \text { to May } 1996^{\text {b }} & 12 \\ \text { June } 1995 \text { to May } 1997^{\text {bc }} & 24 \\ \text { June } 1996 \text { to May } 1998^{c} & 24\end{array}$

Drained 1970

June 1993 to September $1993^{\mathrm{d}} 4$

June 1993 to May $1994^{\text {d }} 12$

June 1994 to September $1994^{\mathrm{d}} 4$

June 1994 to May $1995^{\text {d }} 12$

June 1995 to May $1996^{\mathrm{b}} \quad 12$

June 1995 to May $1997^{\text {bc }} 24$

June 1996 to May $1998^{c} \quad 24$

Drained $1961 \quad$ June 1993 to September $1993^{\mathrm{d}} 4$

June 1993 to May $1994^{\text {d }} 12$

June 1994 to September $1994^{\text {d }} 4$

June 1994 to May $1995^{\mathrm{d}} 12$

June 1995 to May $1996^{\mathrm{b}} \quad 12$

June 1995 to May $1997^{\text {bc }} 24$

June 1996 to May $1998^{c} \quad 24$

Drained $1937 \quad$ June 1993 to September $1993^{\mathrm{d}} 4$

June 1993 to May $1994^{\text {d }} 12$

June 1994 to September $1994^{\text {d }} 4$

Soil nutrient gradient

All sites

June 1992 to September $1992^{\text {a }} 4$

June 1992 to May $1993^{\text {a }} 12$

June 1993 to September $1993^{\text {a }} 4$

June 1993 to May $1994^{\text {a }} 12$

June 1994 to September $1994^{\text {a }} 4$

June 1994 to May $1995^{\text {a }} 12$ 
Table 4. Variation in some weather parameters during the study period in the Lakkasuo mire complex, where the undrained site and the mesotrophic and meso-oligotrophic sites drained in 1961 are located. The pattern of between-year variation in the other sites was similar.

\begin{tabular}{lccccccc}
\hline Variable & 1992 & 1993 & 1994 & 1995 & 1996 & 1997 & 1998 \\
& & & & & & & \\
\hline January mean temp. $^{\text {a }}$ & -3.6 & -3.5 & -6.7 & -4.6 & -7.1 & -6.8 & -3.9 \\
July mean temp. $^{\mathrm{a}}$ & 14.8 & 15.1 & 18.4 & 14.7 & 13.4 & 17.5 & \\
Temperature sum $^{\text {ab }}$ & 1219 & 997 & 1156 & 1231 & 1074 & 1307 & \\
Summer precip. $^{\mathrm{c}}$ & 323 & 280 & 249 & 238 & 236 & 299 & \\
Winter precip. $^{\mathrm{d}}$ & 320 & 323 & 440 & 273 & 401 & 334 & \\
\hline
\end{tabular}

${ }^{\text {a }}$ Air temperature at $2 \mathrm{~m}$ in the open, ${ }^{\circ} \mathrm{C}$

${ }^{\mathrm{b}}$ Degree days, $+5^{\circ} \mathrm{C}$ threshold

${ }^{\mathrm{c}}$ Precipitation, mm, during June-September

${ }^{\mathrm{d}}$ Precipitation, mm, during October-May (of the next year) 
Table 5. Drainage succession gradient data: Mean mass loss, $\%$ of dry mass, and its standard error for each litter type, site, and incubation period. Two incubation depths for root litter.

\begin{tabular}{|c|c|c|c|c|c|c|c|}
\hline \multirow[t]{3}{*}{ Site } & \multirow{3}{*}{$\begin{array}{l}\text { Starting } \\
\text { year }\end{array}$} & \multirow{3}{*}{$\begin{array}{l}\text { Period, } \\
\text { months }\end{array}$} & \multirow{3}{*}{ Needles } & -Mass & loss, $\%$ & & \\
\hline & & & & Smal & roots & \multicolumn{2}{|c|}{ Fine roots } \\
\hline & & & & $0-10 \mathrm{~cm}$ & $10-20 \mathrm{~cm}$ & $0-10 \mathrm{~cm}$ & $10-20 \mathrm{~cm}$ \\
\hline \multirow[t]{3}{*}{ Undrained } & 1995 & 12 & $39(1.7)$ & $22(0.7)$ & $25(1.0)$ & $36(1.5)$ & $34(1.1)$ \\
\hline & 1995 & 24 & $57(2.9)$ & $33(2.1)$ & $28(0.7)$ & $48(1.8)$ & $40(1.2)$ \\
\hline & 1996 & 24 & $65(1.7)$ & & & $56(1.3)$ & $44(1.0)$ \\
\hline \multirow[t]{7}{*}{ Drained 1970} & 1993 & 4 & $35(0.9)$ & $24(0.9)$ & $22(0.6)$ & $38(0.6)$ & $35(0.8)$ \\
\hline & 1993 & 12 & $40(0.7)$ & $27(0.7)$ & $25(1.0)$ & $42(1.0)$ & $41(1.7)$ \\
\hline & 1994 & 4 & $25(1.1)$ & $22(1.4)$ & $20(0.9)$ & $32(0.7)$ & $28(1.7)$ \\
\hline & 1994 & 12 & $34(1.1)$ & $27(0.8)$ & $26(0.6)$ & $35(1.2)$ & $32(1.2)$ \\
\hline & 1995 & 12 & $33(1.1)$ & $21(0.9)$ & $20(0.7)$ & $36(1.0)$ & $34(1.1)$ \\
\hline & 1995 & 24 & $46(2.0)$ & $36(1.6)$ & $33(0.8)$ & $44(1.7)$ & $44(1.0)$ \\
\hline & 1996 & 24 & $52(1.0)$ & $41(1.2)$ & $39(0.8)$ & $45(1.3)$ & $46(0.8)$ \\
\hline \multirow[t]{7}{*}{ Drained 1961} & $1993^{a}$ & 4 & $31(1.0)$ & $22(0.5)$ & $18(0.6)$ & $41(1.0)$ & $33(1.0)$ \\
\hline & $1993^{a}$ & 12 & $39(0.6)$ & $25(0.5)$ & $20(0.7)$ & $44(1.0)$ & $35(1.3)$ \\
\hline & $1994^{\mathrm{a}}$ & 4 & $29(1.4)$ & $19(0.7)$ & $18(0.5)$ & $36(1.2)$ & $29(1.4)$ \\
\hline & $1994^{\mathrm{a}}$ & 12 & $35(0.8)$ & $22(0.9)$ & $18(0.7)$ & $40(1.9)$ & $29(2.9)$ \\
\hline & 1995 & 12 & $38(0.9)$ & $23(0.7)$ & $26(3.3)$ & $35(1.1)$ & $29(2.2)$ \\
\hline & 1995 & 24 & $48(1.0)$ & $33(1.4)$ & $29(1.5)$ & $40(2.2)$ & $22(2.1)$ \\
\hline & 1996 & 24 & $53(0.7)$ & $38(1.1)$ & $31(0.9)$ & $48(1.3)$ & $39(1.0)$ \\
\hline \multirow[t]{3}{*}{ Drained 1937} & 1993 & 4 & $33(2.0)$ & $23(0.7)$ & $20(0.8)$ & $38(1.5)$ & 34 (1.9) \\
\hline & 1993 & 12 & $45(1.3)$ & $28(0.6)$ & $23(0.8)$ & $40(0.9)$ & 37 (1.9) \\
\hline & 1994 & 4 & $23(1.7)$ & $19(1.3)$ & $14(1.3)$ & $32(1.9)$ & $24(0.8)$ \\
\hline
\end{tabular}

${ }^{a}$ data shared with the soil nutrient gradient data set 
Table 6. Soil nutrient gradient data: Mean mass loss, $\%$ of dry mass, and its standard error for each litter type, site, and incubation period. Two incubation depths for root litter.

\begin{tabular}{|c|c|c|c|c|c|c|c|}
\hline \multirow[t]{3}{*}{ Site } & \multirow{3}{*}{$\begin{array}{l}\text { Starting } \\
\text { year }\end{array}$} & \multirow{3}{*}{$\begin{array}{l}\text { Duration, } \\
\text { months }\end{array}$} & \multirow{3}{*}{ Needles } & -1viase & $10 \mathrm{~s}, \mathrm{C}$ & \multirow{2}{*}{\multicolumn{2}{|c|}{ Fine roots }} \\
\hline & & & & Smal & 1 roots & & \\
\hline & & & & $0-10 \mathrm{~cm}$ & $10-20 \mathrm{~cm}$ & $0-10 \mathrm{~cm}$ & $10-20 \mathrm{~cm}$ \\
\hline \multirow[t]{6}{*}{ Meso-oligotr. } & 1992 & 4 & $41(1.0)$ & $24(1.1)$ & $20(0.7)$ & $33(1.6)$ & $31(1.3)$ \\
\hline & 1992 & 12 & 48 (1.6) & $31(1.0)$ & $24(0.5)$ & $37(2.3)$ & $34(2.2)$ \\
\hline & 1993 & 4 & $35(1.5)$ & $23(1.0)$ & $19(0.4)$ & $40(0.8)$ & $34(0.6)$ \\
\hline & 1993 & 12 & $42(1.0)$ & $26(0.6)$ & $23(0.4)$ & $43(1.4)$ & $37(0.9)$ \\
\hline & 1994 & 4 & $33(1.3)$ & $20(1.0)$ & $17(0.9)$ & $33(1.1)$ & $26(1.0)$ \\
\hline & 1994 & 12 & $41(0.9)$ & $28(1.0)$ & $23(1.0)$ & $40(1.4)$ & $27(1.8)$ \\
\hline \multirow[t]{6}{*}{ Oligotrophic } & 1992 & 4 & $39(0.5)$ & $24(0.8)$ & $18(0.8)$ & $37(1.0)$ & $33(1.2)$ \\
\hline & 1992 & 12 & $48(1.0)$ & $32(0.8)$ & $27(1.0)$ & 39 (1.8) & $30(2.1)$ \\
\hline & $1993^{a}$ & 4 & $31(1.0)$ & $22(0.5)$ & $18(0.6)$ & $41(1.0)$ & $33(1.0)$ \\
\hline & $1993^{a}$ & 12 & $39(0.6)$ & $25(0.5)$ & $20(0.5)$ & $44(1.0)$ & $35(1.3)$ \\
\hline & $1994^{\mathrm{a}}$ & 4 & $29(1.4)$ & $19(0.7)$ & $18(0.5)$ & $36(1.2)$ & $29(1.4)$ \\
\hline & $1994^{\mathrm{a}}$ & 12 & $35(0.8)$ & $22(0.8)$ & $18(0.7)$ & $40(1.9)$ & $27(2.0)$ \\
\hline \multirow[t]{6}{*}{ Ombrotrophic } & 1992 & 4 & $33(0.8)$ & $19(0.4)$ & $19(0.4)$ & $33(0.6)$ & $32(0.7)$ \\
\hline & 1992 & 12 & $40(1.0)$ & $25(0.8)$ & $24(0.5)$ & $37(1.4)$ & $33(1.2)$ \\
\hline & 1993 & 4 & $33(1.5)$ & $19(0.6)$ & $18(0.6)$ & $41(0.7)$ & $39(0.7)$ \\
\hline & 1993 & 12 & $39(0.9)$ & $25(0.8)$ & $23(0.5)$ & $54(2.6)$ & $48(3.2)$ \\
\hline & 1994 & 4 & $23(1.3)$ & $20(0.8)$ & $17(0.8)$ & $35(0.9)$ & $26(1.5)$ \\
\hline & 1994 & 12 & $35(1.0)$ & $25(0.9)$ & $20(0.9)$ & $42(0.6)$ & $37(1.0)$ \\
\hline
\end{tabular}

${ }^{a}$ data shared with the drainage succession gradient data set 
Table 7. Models for mass losses in the whole material. Standard errors in parentheses. In the random part, significant variance components are presented. Independent variables are listed in order of decreasing significance (as indicated by the coefficient:s.e.e. ratio).

$\mathrm{P}_{\text {winter }}=$ winter (October-May) precipitation sum of the incubation period, $\mathrm{mm} ; \mathrm{P}_{\text {summer }}=$ summer (June-September) precipitation sum of the incubation period, $\mathrm{mm}$; TS = cumulative temperature sum of the incubation period (air, $5^{\circ} \mathrm{C}$ threshold), degree-days; $\mathrm{TW}=$ winter mean temperature; $\mathrm{WT}=$ average growing season water level, $\mathrm{cm} ; \mathrm{N}=$ nitrogen concentration in the surface peat $(0-20 \mathrm{~cm})$ of the incubation site, $\%$ of dry mass; Depth $=$ incubation depth $(0-10 \mathrm{~cm}$ or $10-20 \mathrm{~cm}$; average depths $5 \mathrm{~cm}$ and $15 \mathrm{~cm}$ used in the model); $\mathrm{V}=$ tree stand volume of the incubation site, $\mathrm{m}^{3} \mathrm{ha}^{-1} ;$ Birch $=$ proportion of birch of V. Numbers 1 and 2 in weather variables refer to the year of incubation ( $\max$ 2 years). Within-site $=$ within-site heterogeneity.

Fixed part

Effect
Coefficient

\section{Random part}

Effect

Variance component

$\begin{array}{lll}\text { Needle litter } & & \\ \text { Constant } & 2.97 & (14.60) \\ \mathrm{P}_{\text {winter1 }} & 0.0233 & (0.00171) \\ \mathrm{TS} 2 & 0.0119 & (0.00096) \\ \mathrm{P}_{\text {summer1 }} & 0.0916 & (0.0353) \\ \mathrm{P}_{\text {winter1 }} / \mathrm{TW} 1 & -0.00064 & (0.00027) \\ \mathrm{WT} & -0.171 & (0.072) \\ \mathrm{N} & 6.28 & (3.35)\end{array}$

Fine root litter (diameter $<2 \mathrm{~mm}$ )

$\begin{array}{lll}\text { Constant } & 11.35 & (22.72) \\ \text { Depth } & -0.569 & (0.036) \\ \mathrm{P}_{\text {winter1 }} & 0.00849 & (0.00120) \\ \mathrm{TS}_{1} & -0.0794 & (0.0214) \\ \mathrm{V} & -0.0453 & (0.0138) \\ \mathrm{P}_{\text {summer2 }} & 0.0987 & (0.0300) \\ \mathrm{P}_{\text {summer1 }} & 0.245 & (0.082) \\ \mathrm{TS}_{1 / \mathrm{P}_{\text {summer1 }}} & 13.41 & (5.53) \\ \mathrm{TS}_{2} & -0.0142 & (0.0074) \\ \mathrm{P}_{\text {winter2 }} & -0.0101 & (0.0096)\end{array}$

Small root litter (diameter 2-5 $\mathrm{mm}$ )

$\begin{array}{lcl}\text { Constant } & 15.70 & (0.947) \\ \mathrm{P}_{\text {winter }} & 0.0120 & (0.00073) \\ \text { Depth } & -0.310 & (0.0232) \\ \mathrm{P}_{\text {summer }} & 0.0226 & (0.00232) \\ \text { Birch } & 10.92 & (4.16)\end{array}$

Starting-year $\quad 19.00 \quad(8.03)$

Within-site $\quad 35.40 \quad(1.88)$ $\begin{array}{lrr}\text { Starting-year } & 3.50 & (1.24) \\ \text { Within-site } & 17.40 & (0.69)\end{array}$ 
Appendix 1. Drainage succession gradient data: Repeated measures ANOVA tables for each litter type.

\begin{tabular}{|c|c|c|c|c|c|c|c|c|c|}
\hline \multirow[t]{2}{*}{ Source of variation } & \multicolumn{3}{|c|}{ Needles } & \multicolumn{3}{|c|}{ Small roots } & \multicolumn{3}{|c|}{ Fine roots } \\
\hline & df & $\mathrm{F}$ & $\mathrm{p}$ & df & $\mathrm{F}$ & $\mathrm{p}$ & df & $\mathrm{F}$ & $\mathrm{p}$ \\
\hline \multicolumn{10}{|c|}{ Set $b$ (Table 3): 12 and 24 month mass loss among the undrained and drained sites } \\
\hline Site & 2 & 9.8 & $<0.001$ & 2 & 0.1 & 0.884 & 2 & 21.0 & $<0.001$ \\
\hline \multicolumn{10}{|l|}{ Within subjects } \\
\hline Time & 1 & 129.8 & $<0.001$ & 1 & 100.7 & $<0.001$ & 1 & 62.3 & $<0.001$ \\
\hline Time*site & 2 & 3.8 & 0.028 & 2 & 7.6 & 0.001 & 2 & 20.0 & $<0.001$ \\
\hline Depth & & & & 1 & 1.0 & 0.327 & 1 & 34.2 & $<0.001$ \\
\hline Depth*site & & & & 2 & 0.4 & 0.643 & 2 & 8.9 & $<0.001$ \\
\hline Time*depth & & & & 1 & 12.0 & 0.001 & 1 & 16.2 & $<0.001$ \\
\hline Time*depth*site & & & & 2 & 0.9 & 0.400 & 2 & 10.9 & $<0.001$ \\
\hline Error & 54 & & & 48 & & & 56 & & \\
\hline
\end{tabular}

Set c: 24-month mass loss among the undrained and drained sites

Between subjects

\begin{tabular}{|c|c|c|c|c|c|c|c|c|c|}
\hline Site & 2 & 23.0 & $<0.001$ & 2 & 13.9 & $<0.001$ & 2 & 38.9 & $<0.001$ \\
\hline Year & 1 & 15.0 & $<0.001$ & 1 & 23.8 & $<0.001$ & 1 & 45.9 & $<0.001$ \\
\hline Site* year & 2 & 0.5 & 0.610 & 1 & 1.8 & 0.180 & 2 & 10.1 & $<0.001$ \\
\hline \multicolumn{10}{|l|}{ Within subjects } \\
\hline Depth & & & & 1 & 24.1 & $<0.001$ & 1 & 86.6 & $<0.001$ \\
\hline Depth*site & & & & 2 & 1.1 & 0.332 & 2 & 25.9 & $<0.001$ \\
\hline Depth*year & & & & 1 & 0.3 & 0.586 & 1 & 0.6 & 0.426 \\
\hline Depth*site*year & & & & 1 & 1.6 & 0.210 & 2 & 4.7 & 0.011 \\
\hline Error & 111 & & & 80 & & & 113 & & \\
\hline
\end{tabular}

Set d: $\mathbf{4}$ and 12 month mass loss among drained sites

Between subjects

$\begin{array}{lrrrrrrrrr}\text { Site } & 2 & 2.7 & 0.074 & 2 & 33.1 & <0.001 & 2 & 0.9 & 0.404 \\ \text { Year } & 1 & 37.0 & <0.001 & 1 & 7.7 & 0.007 & 1 & 45.7 & <0.001 \\ \text { Site* year } & 1 & 4.8 & 0.030 & 1 & 3.2 & 0.075 & 1 & 2.6 & 0.112 \\ \text { Within subjects } & & & & & & & & & \\ \text { Time } & 1 & 187.0 & <0.001 & 1 & 113.7 & <0.001 & 1 & 28.8 & <0.001 \\ \text { Time*site } & 2 & 6.0 & 0.003 & 2 & 6.8 & 0.002 & 2 & 1.1 & 0.344 \\ \text { Time* year } & 1 & 0.1 & 0.786 & 1 & 1.4 & 0.233 & 1 & 0.2 & 0.650 \\ \text { Time*site*year } & 1 & 3.2 & 0.075 & 1 & 5.2 & 0.024 & 1 & 0.2 & 0.632 \\ \text { Depth } & & & & 1 & 60.8 & <0.001 & 1 & 64.5 & <0.001 \\ \text { Depth*site } & & & & 2 & 2.7 & 0.074 & 2 & 10.7 & <0.001 \\ \text { Depth*year } & & & & 1 & 2.7 & 0.106 & 1 & 0.9 & 0.345 \\ \text { Depth*site*year } & & & & 1 & 0.6 & 0.457 & 1 & 0.5 & 0.481 \\ \text { Time*depth } & & & & 1 & 2.2 & 0.145 & 1 & <0.1 & 0.899 \\ \text { Time*depth*site } & & & & 2 & 1.1 & 0.350 & 2 & 1.1 & 0.341 \\ \text { Time*depth*year } & & & & 1 & 0.1 & 0.720 & 1 & 0.8 & 0.388 \\ \text { Time*depth*site*year } & & & & 1 & 0.1 & 0.757 & 1 & <0.1 & 0.826 \\ \text { Error } & 95 & & & 84 & & & 95 & & \\ & & & & & & & & & \end{array}$


Appendix 2. Soil nutrient gradient data: Repeated measures ANOVA table for each litter type. (Set a, Table 3.)

\begin{tabular}{|c|c|c|c|c|c|c|c|c|c|}
\hline \multirow[t]{2}{*}{ Source of variation } & \multicolumn{3}{|c|}{ Needles } & \multicolumn{3}{|c|}{ Small roots } & \multicolumn{3}{|c|}{ Fine roots } \\
\hline & $\mathrm{df}$ & $\mathrm{F}$ & $\mathrm{p}$ & df & $\mathrm{F}$ & $\mathrm{p}$ & df & $\mathrm{F}$ & $\mathrm{p}$ \\
\hline \multicolumn{10}{|l|}{ Between subjects } \\
\hline Site & 2 & 33.6 & $<0.001$ & 2 & 15.1 & $<0.001$ & 2 & 11.2 & $<0.001$ \\
\hline Year & 2 & 66.6 & $<0.001$ & 2 & 47.1 & $<0.001$ & 2 & 59.2 & $<0.001$ \\
\hline Site* year & 4 & 5.2 & 0.001 & 4 & 6.3 & $<0.001$ & 4 & 6.3 & $<0.001$ \\
\hline \multicolumn{10}{|l|}{ Within subjects } \\
\hline Time & 1 & 348.6 & $<0.001$ & 1 & 341.7 & $<0.001$ & 1 & 86.5 & $<0.001$ \\
\hline Time* site & 2 & 1.2 & 0.289 & 2 & 1.2 & 0.296 & 2 & 17.8 & $<0.001$ \\
\hline Time* year & 2 & 1.2 & 0.297 & 2 & 10.6 & $<0.001$ & 2 & 8.3 & $<0.001$ \\
\hline Time* site*year & 4 & 3.9 & 0.004 & 4 & 9.9 & $<0.001$ & 4 & 3.3 & 0.012 \\
\hline Depth & & & & 1 & 181.1 & $<0.001$ & 1 & 173.6 & $<0.001$ \\
\hline Depth*site & & & & 2 & 8.0 & $<0.001$ & 2 & 6.5 & 0.002 \\
\hline Depth*year & & & & 2 & $<0.1$ & 0.960 & 2 & 8.8 & $<0.001$ \\
\hline Depth*site*year & & & & 4 & 5.2 & 0.001 & 4 & 0.7 & 0.625 \\
\hline Time*depth & & & & 1 & 8.4 & 0.004 & 1 & 11.4 & 0.001 \\
\hline Time*depth*site & & & & 2 & 0.4 & 0.636 & 2 & 1.0 & 0.389 \\
\hline Time*depth*year & & & & 2 & 3.5 & 0.034 & 2 & 0.8 & 0.457 \\
\hline Time*depth* site*year & & & & 4 & 1.5 & 0.216 & 4 & 2.8 & 0.029 \\
\hline Error & 164 & & & 158 & & & 161 & & \\
\hline
\end{tabular}



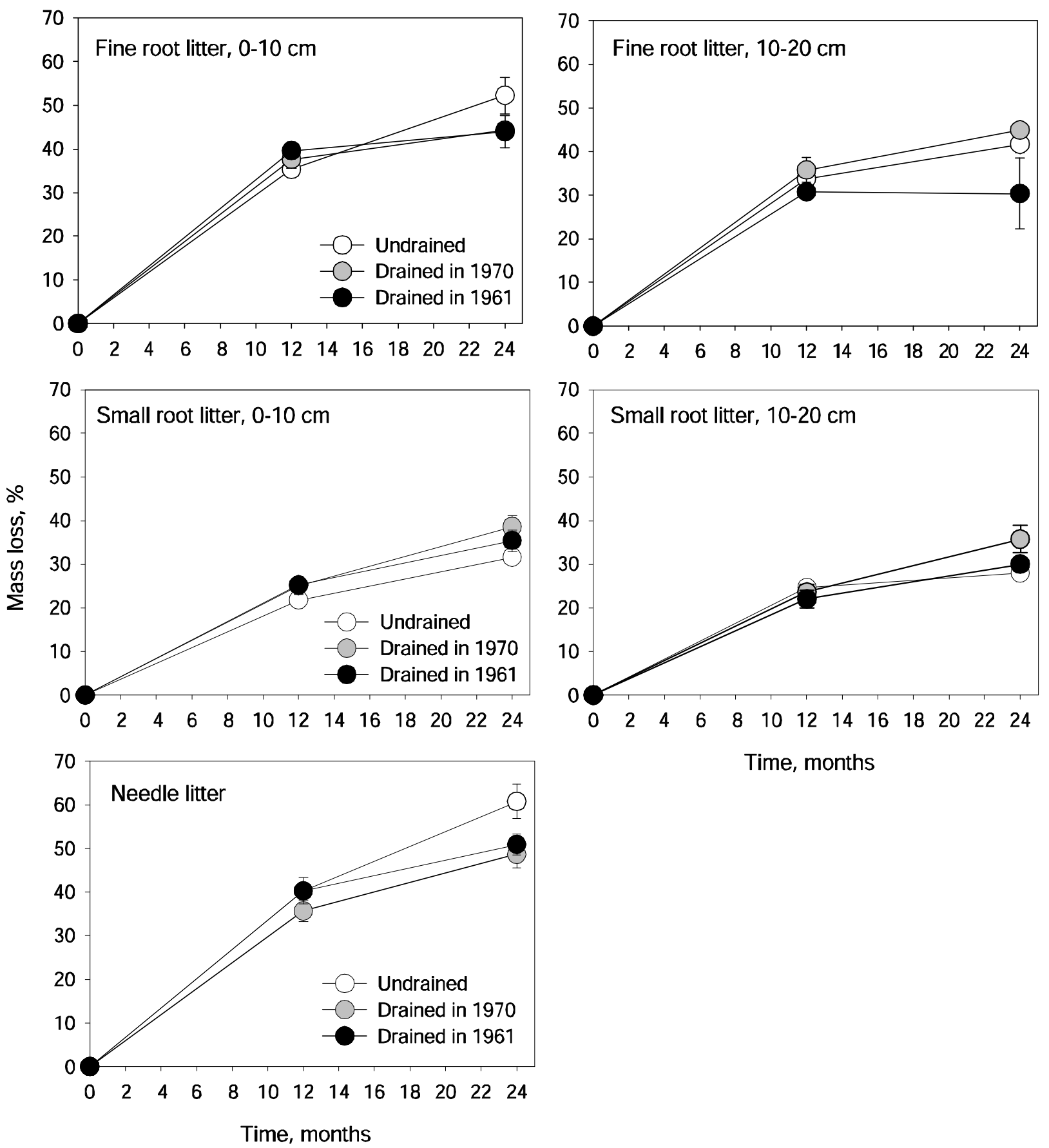

Time, months

Fig. 1. Drainage succession gradient data: Mean mass loss values, $\%$, and their standard errors for 12- and 24-month incubations. Incubation started in the end of May. Needle litter was incubated within the moss layer. Root litter was incubated in either the $0-10 \mathrm{~cm}$ or the $10-20 \mathrm{~cm}$ peat layer (zero-level below the living moss layer). 

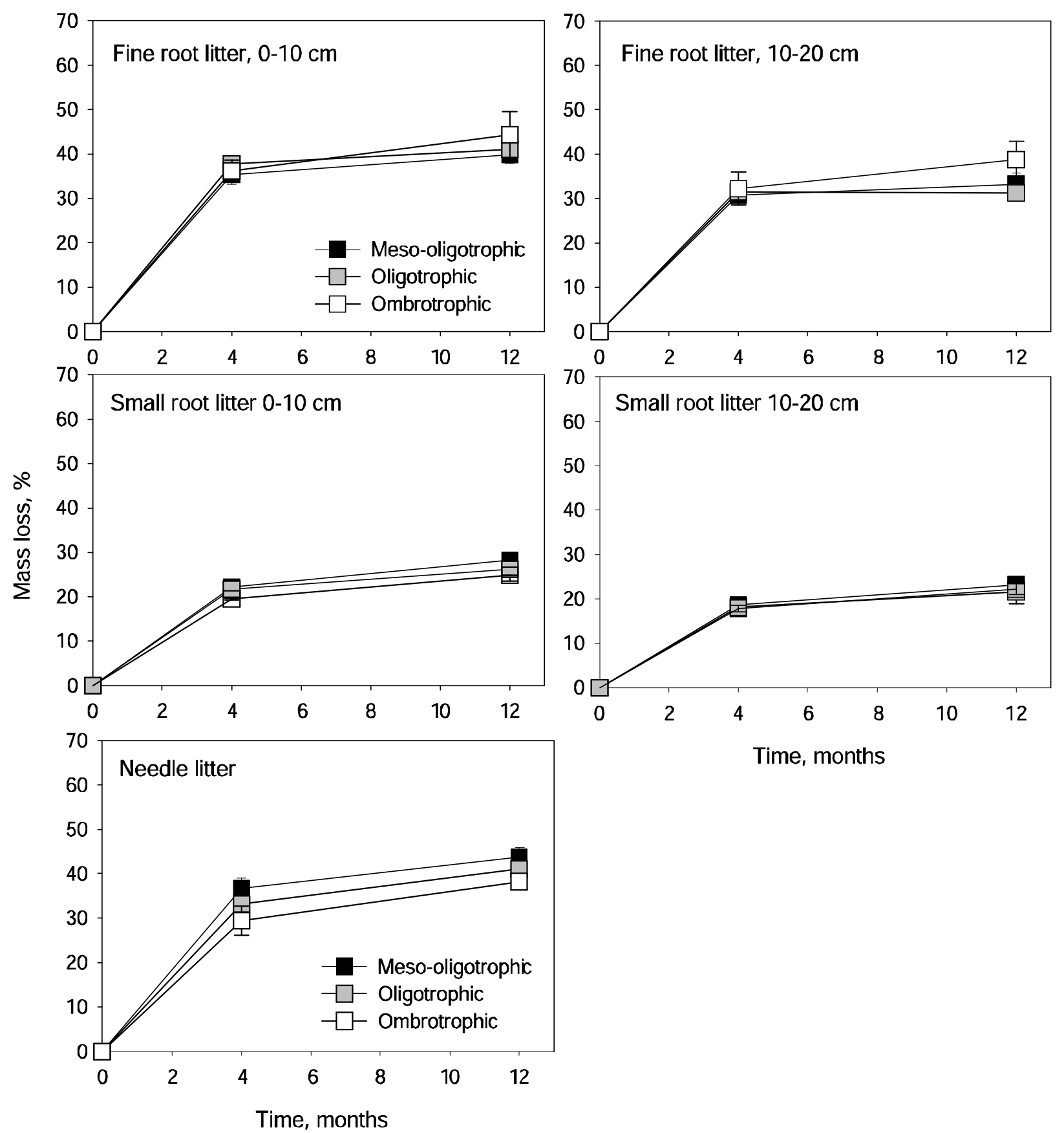

Time, months

Fig. 2. Soil nutrient gradient data: Mean mass loss values, $\%$, and their standard errors for each litter type and length of incubation per site. Incubation started in the end of May. The four-month incubation covers the growing-season ending in the end of September. Needle litter was incubated within the moss layer. Root litter was incubated in either the $0-10 \mathrm{~cm}$ or the $10-20 \mathrm{~cm}$ peat layer. 


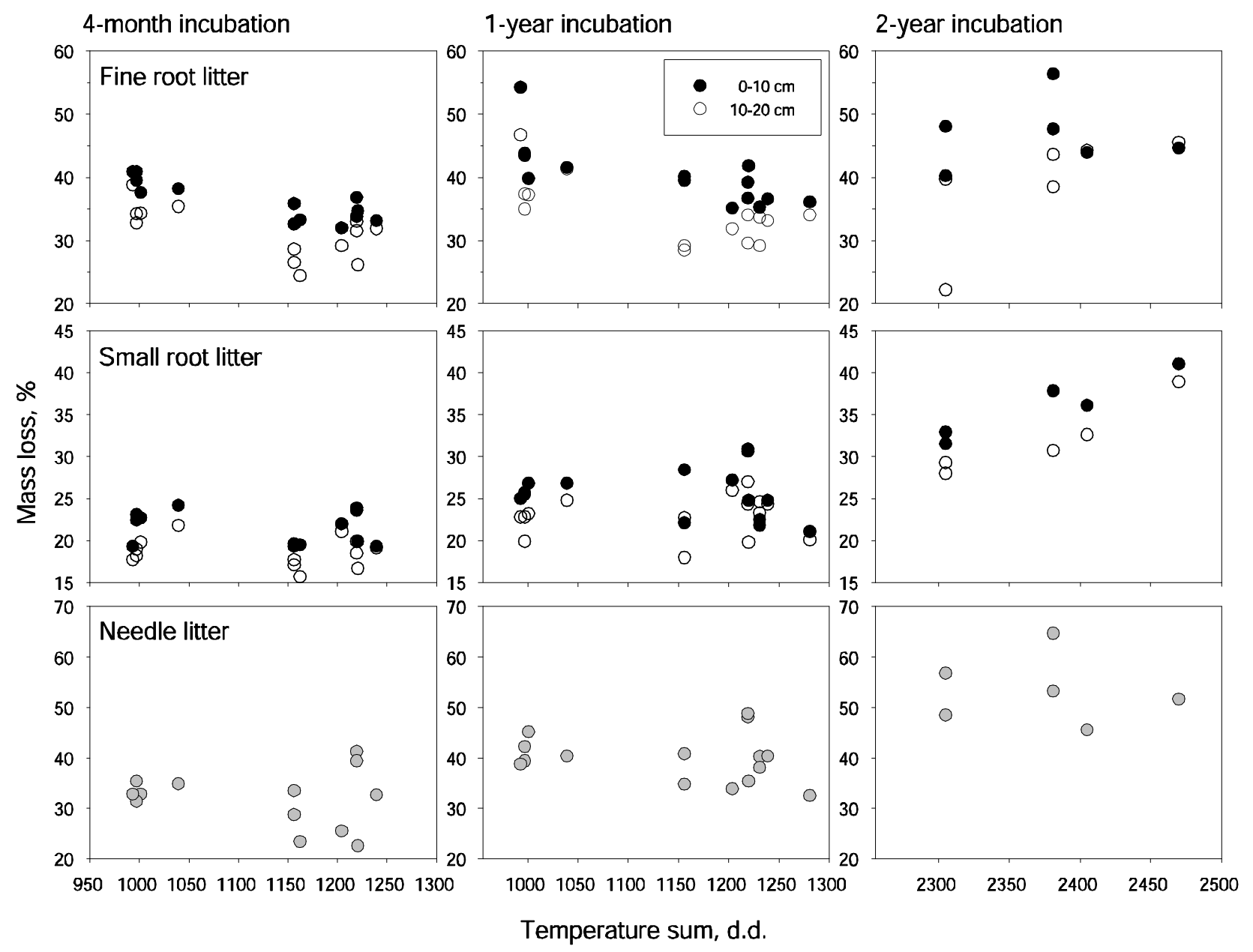

Fig. 3. Scots pine litter mass loss, $\%$, related to the cumulative temperature sum (air, $5^{\circ} \mathrm{C}$ threshold), degree days, during 4-, 12- and 24-month incubation periods. Values are means for each site and incubation period. Black circles $=0-10 \mathrm{~cm}$ incubation depth, open circles $=10-20 \mathrm{~cm}$. (Note that these are not all independent observations: see data structure description in Statistical analyses). 


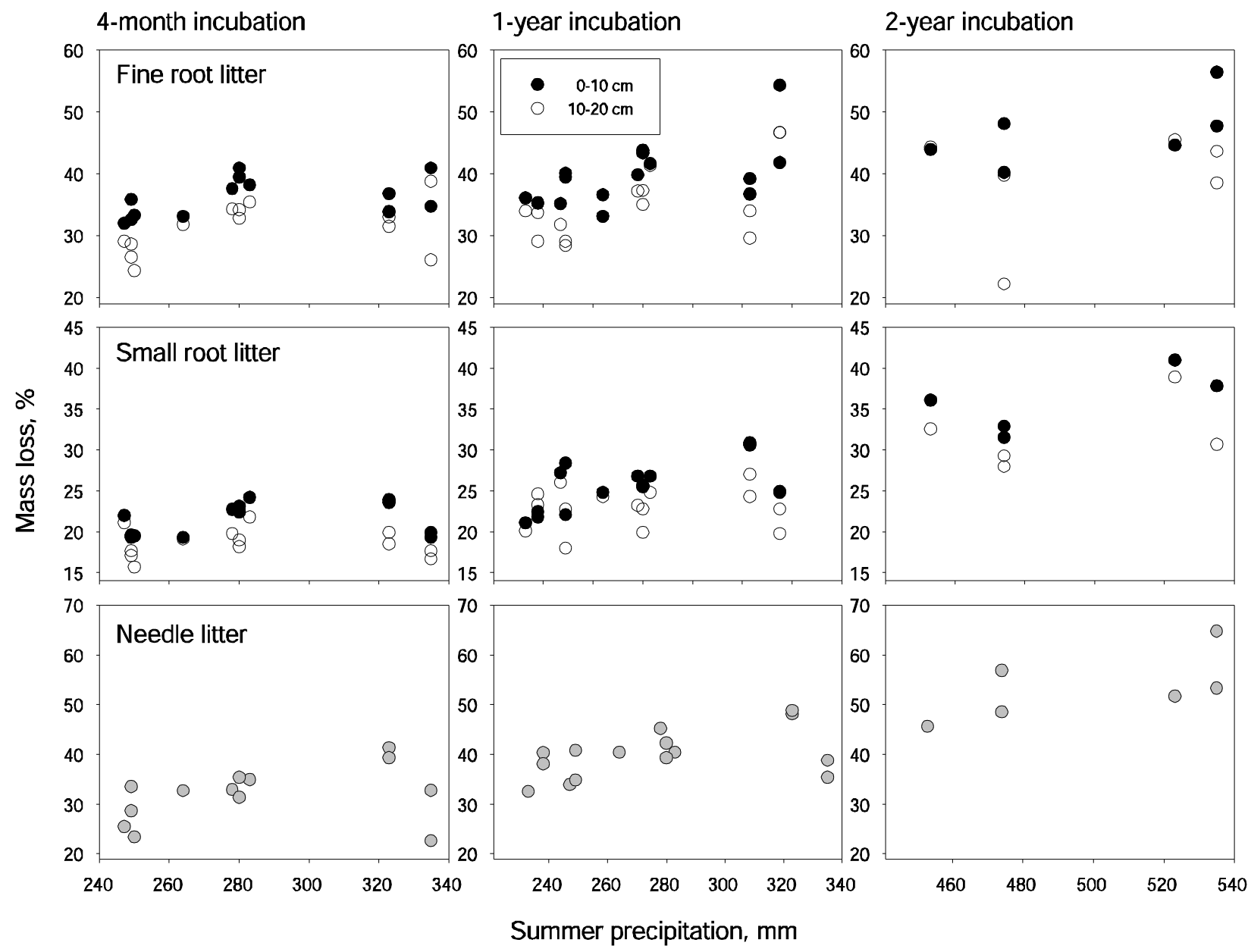

Fig. 4. Scots pine litter mass loss, \%, related to the cumulative summer (June-September) precipitation, mm, during 4-, 12- and 24-month incubation periods. Black circles $=0-10 \mathrm{~cm}$ incubation depth, open circles $=10-20 \mathrm{~cm}$. 


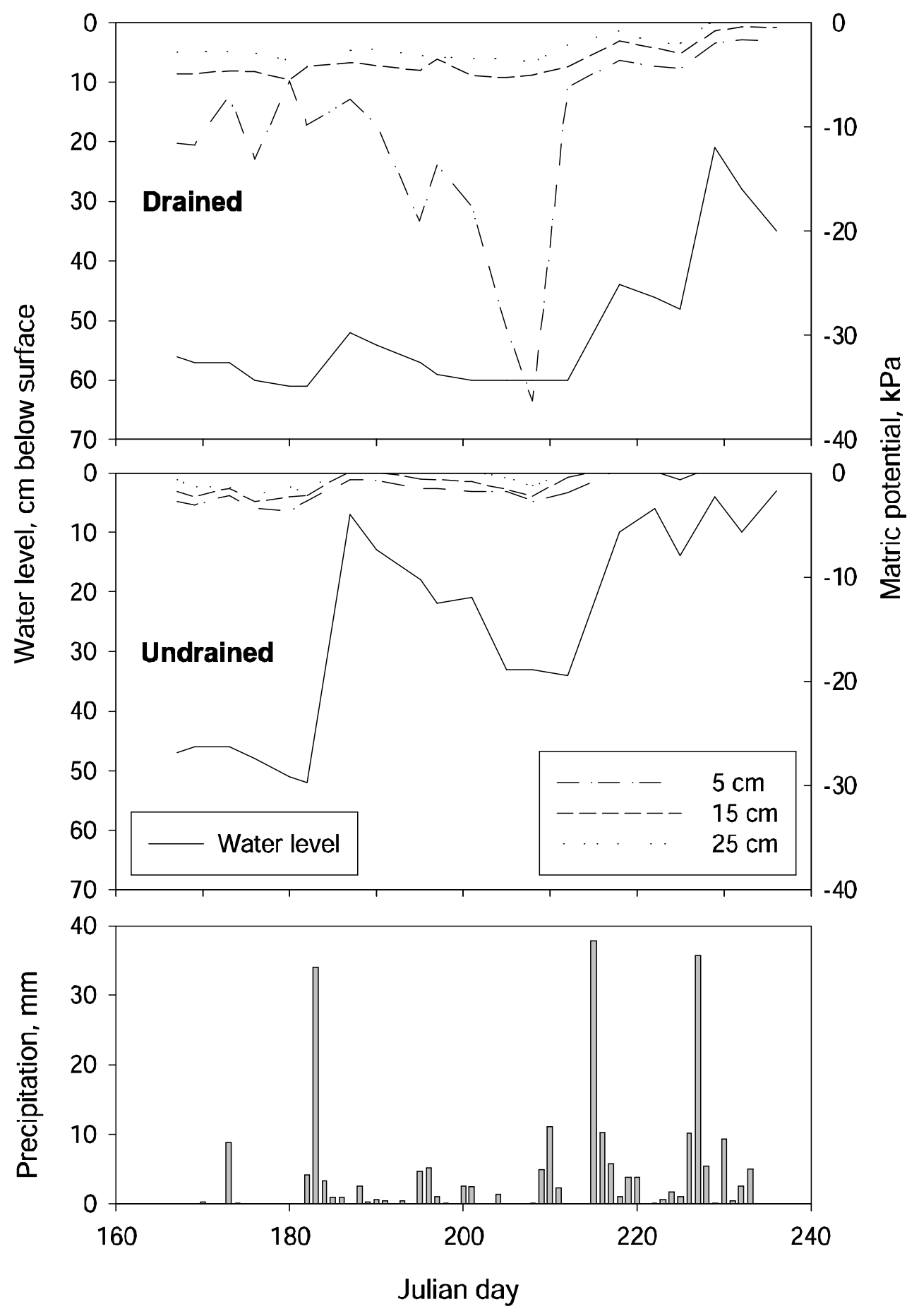

Fig. 5. Water level (scale left) and soil matric potential at 5, 15, and $25 \mathrm{~cm}$ depths (scale right) on the oligotrophic site, drained in 1961 (topmost graph) and the undrained (middle graph) site. Time scale extends from June 16 to August 24, 1992. The lowest graph shows precipitation during this time. Matric potential (the tension with which water is held in the soil) was measured using pressure tranducer tensiometers (J. Laine, unpublished data). In the drained site, measurements were done at $15 \mathrm{~m}$ distance from a drainage ditch. 